\title{
Migration and the Feminization of Power: A Reading of Mike Bamiloye's Transnational Films
}

\section{Elizabeth Olayiwola ${ }^{1}$}

\begin{abstract}
${ }^{1}$ SHORT BIO
Elizabeth Olayiwola is a lecturer in the Department of Film and Film Production at Kwara State University, Malete, Nigeria. Her research interests cut across gender, religion, and film studies.
\end{abstract}

\section{INSTITUTIONAL AFFILIATION}

Kwara State University, Nigeria

elizabeth.olayiwola@kwasu.edu.ng

ORCID

https://orcid.org/0000-0002-1969-7958

\begin{abstract}
In Nigeria and many other African countries, husbands are regarded as breadwinners and "lords of the household". When women get married, they are described as "going to their husband's house," and in cases of separation or unresolved crisis within the union, the wives are "sent out" of the household. These ways of framing gendered relationships in marriage provide the basis for popular stories in many conventional Nollywood videos. However, as Mount Zion Film Productions, an evangelical video production company based in Nigeria and led by filmmaker Mike Bamiloye, has crossed national borders, it has also reflected on the changing gender roles and identities of migrant women. In each transnational Mount Zion video, the filmmaker struggles to square cultural and biblical constructions of gender roles. In a diasporic milieu, Bamiloye's cultural-religious imagination of womanhood is contested. Drawing on three transnational Mount Zion films (The Return, Prodigal Ones, and The Finest Wine), this article uses content analysis methods to study the selected films and to explore the conflict and dynamism generated by the emergence of newly profiled migrant women.
\end{abstract}

\section{KEYWORDS}

Migrant, women, feminization of power, transnational, evangelical, Nollywood, Mount Zion Film Productions

\section{Introduction}

Many observers have reported that the image of women is poorly represented on the Nigerian film screen. This unfavorable representation is often attributed to male dominance of the Nigerian film industry, popularly referred to as Nollywood. The spread of Nigerian films outside its home country has generated an extensive body of literature on the transnational dimension of Nollywood. ${ }^{2}$ However, little attention has been devoted to

2 Examples of this literature include Moradewun Adejunmobi, "Charting Nollywood's Appeal Locally and Globally," Film African Literature Today 28 (2010): 106-21; Moradewun Adejunmobi, "Nollywood, Globalization, and Regional Media Corporations 
how a transnational space can challenge the conventional stereotypical representation of women in Nigerian films. Also, the nexus between filmmakers' religious beliefs and their representational practice is underresearched.

In this article, I argue that transnational spaces can wield significant influence even over a culturally and religiously committed filmmaker such as Mike Bamiloye, the founder of Mount Zion Film Productions, and arguably the best-known evangelical Christian in the Nigerian film industry. Drawing on three Mount Zion films, I show how gendered understandings of power, influenced by cultural and religious interpretation, function in the transnational space represented in the films. Mount Zion Film Productions (MZFP), founded in southwest Nigeria in 1985, has become the most popular and prolific evangelical film company in Nigeria. In the late 1990s and early 2000s, representatives of MZFP began to travel beyond Nigeria to produce films, mainly in conjunction with transnational churches. Many films, including the three examined in this article, have emerged from such collaborations. In the selected films, relocating to a new geographical space seems to be the dominant factor in the liberation of women. Therefore, in this article I emphasize how Bamiloye portrays and engages with depictions of the roles and identity of women in diasporic spaces.

Studies of Nollywood have generally argued that most Nigerian films misrepresent women and do not portray their actual, more progressive contemporary experiences. In contrast, I argue here that Bamiloye's national films have been relatively progressive in their representation of women; Bamiloye contends with different realities from his peers as he

in Africa," Popular Communication 9, no. 2 (2011): 67-78; Alessandro Jedlowski, "From Nollywood to Nollyworld: Processes of Transnationalization in the Nigerian Video Film Industry," in Global Nollywood: The Transnational Dimensions of an African Video Film Industry, ed. Matthias Krings and Onookome Okome (Bloomington: Indiana University Press, 2013), 25-45; Jordache Ellapen and Jyoti Mistry, "Nollywood Transportability: The Politics and Economics of the Video Films as Cultural Products," in Global Nollywood, 46-69; Jonathan Haynes "The Nollywood Diaspora: A Nigerian Video Genre," in Global Nollywood, 73-99; Claudia Hoffmann, "Made in America: Urban Immigrant Spaces in Transnational Nollywood Films," in Global Nollywood, 121-38; Katrina Pype, "Religion, Migration, and Media Aesthetics: Notes on the Circulation and Reception of Nigerian Films in Kinshasa," in Global Nollywood, 199-222. 
The African Journal of Gender and Religion Vol. 26 No 1 (July 2020)

appears to be reframing womanhood for female migrants, based on specific biblical hermeneutics. Below I review the existing literature on the representation of women in Nollywood films and on women and migration, and then use these insights to develop a content analysis of three transnational videos by Mike Bamiloye: The Return (2014), The Prodigal Ones (2008), and The Finest Wine (2013). I selected the three case study films after watching many transnational MZFP films produced within the space of ten years (2008-2018). I have chosen these three transnational films because of their considerable attention to gender relations between husband and wife. My analysis of the selected films is inspired by Roberto Marinucci's (2007) theory of the feminization of power. ${ }^{3}$ The central idea of feminization of power is for women to not only become visible as economically empowered but also capable of making independent choices.

\section{The Representation of Women in Nollywood}

A recurring observation in literature on the representation of women in Nollywood is that women are better off in reality than conventional Nollywood portrayals would have us believe. This gulf between the filmic world and the real world is a significant source of concern for feminist interpretations of Nollywood. The topic of representation is crucial in women's studies, since visual representation eventually shapes our perception of a group and of the self. Bisi Adeleye-Fayemi quotes Andrea Press:

"We do not create representations, even representations of ourselves in the abstract. Representations of gender identity occur within a massive sea of various conflicting images of gender, many of which are propagated by the mass media." 4

The video film phenomenon in Nigeria has opened space for debate over women's role and identity, in both the public and private spheres.

3 Roberto Marinucci, "Feminization of migration?" Revista Interdisciplinar da Mobilidade Humana 15, no. 29 (2007): 6.

4 Bisi Adeleye-Fayemi, "Either One or the Other: Images of Women in Nigerian Television," in Readings in African Popular Culture, ed. Karin Barber (Bloomington: Indiana University Press, 1997), 126. 
Migration and the Feminization of Power: A Reading of Mike Bamiloye's Transnational Films

Onookome Okome views this as an indication of the rising concern for the changing traditional role of women in a postcolonial frame. Like many other writers on the topic, Okome describes the pessimistic portrayal of women in most Nollywood films as a reflection of stereotypes "perpetuated by male patriarchy." 5 Okome reviews the images of women in Nollywood films, pointing out that they frequently show the audience a depraved and weak woman; a morally bankrupt woman; an upstanding but suffering housewife; a bad mother-in-law; or other similarly negative character types. He uses the Christian videos of the filmmaker Helen Ukpabio as a case study, noting that traditional stereotypes similar to those upheld by secular Nollywood also serve as the template for characterizing women in Ukpabio's Christian films.

One of the best Nigerian resources on the representation of women in Nollywood movies is a 2012 special issue of the Makurdi Journal of Arts and Culture. Maureen N. Eke opened the discussion, by commenting that it was "informed by the overwhelming stereotypical representations of women, which decontextualise their lives."6 Eke questions the kind of stories being told about Nigerian women and, by extension, African women. She also reflects on the "objectification or commodification of African women's bodies,"7 wondering why these stereotypes persist. Eke's concern is that the real-life improvements in women's social position appear to be escaping Nollywood filmmakers. She expresses the hope that emerging women directors and producers will tell a better and more realistic story of women.

The same issue contains a similar article on the portrayal of women in Hausa-language films. Here, Asabe Kabir Usman and Aisha Umar Muhammad cite the dominance of male figures in the Nollywood production process as the apparent reason for negative stereotypes of

5 Onookome Okome, "Women, Religion and Video Film in Nigeria," Film International 1 (2004): 4.

6 Maureen N. Eke, "Nollywood and the Woman Palaver: Desperate Women, Bad Women, Witches, and Saints," Makurdi Journal of Arts and Culture 10, no.1 (2012): 2.

$7 \quad$ Eke, "Nollywood and the Woman Palaver," 2. 
The African Journal of Gender and Religion Vol. 26 No 1 (July 2020)

women, particularly their "weeping and unsympathetic character." Usman and Muhammad conclude that female characters are portrayed mainly as evil, blackmailers, quarrelsome, troublesome, not accommodating, proud, uncultured, easily misguided, superstitious, prostitutes, husband snatchers, evil co-wives, gossips and rumor mongers.

"The depiction of these women characters in Kirjin Biki (a Kannywood" movie title) fails to show them in ways which echo the solid reality of things in the real world. Such depictions imply that women are outlaws and evil presences in their families and society as a whole." 10 The authors argue that, while women do have an inferior and dependent status in Hausa society, they are not devoid of virtue, as portrayed in the movies. They thus conclude that the representation of women in most Kannywood movies is neither realistic nor holistic.

In Christine Odi's analysis of motherhood in five films, several common misrepresentations are highlighted. First, she notes that the mothers were subsumed within the identities and personalities of their husbands and children. Second, she observes that the mother characters are not proportionately, logically, or sequentially developed relative to other roles in the films. Third, the mothers, for the most part, merely hover in the shadows of their children and husbands, not making any meaningful contributions to the affairs of the family or to the general development of the story. Fourth, the mothers often function as sacrificial lambs who save the family from disaster, chaos, and anarchy. Finally, "the worth of mothers as human, persons of value in the family and society is not recognized or celebrated in any way in the films." 11

Gowon Doki agrees that the portrayal of women in Nollywood fails to show the positive changes in women's roles in actual society. After reviewing

Asabe Kabir Usman and Aisha Umar Muhammad, "Women in Hausa Home Movies: Lessons from Kirjin Biki (Master of Ceremony)." Makurdi Journal of Arts and Culture 10, no. 1 (2012): 27.

$9 \quad$ Kannywood is the Hausa language subset of the Nigerian film industry.

10 Usman and Muhammad, "Women in Hausa Home Movies," 34.

11 Christine Odi, "Nollywood Mothering: Motherhood in Selected Nigerian Films," Makurdi Journal of Arts and Culture 10, no. 1 (2012): 69. 
Migration and the Feminization of Power: A Reading of Mike Bamiloye's Transnational Films

eighteen Nollywood films, Doki states emphatically that women tend to be depicted as less ambitious than men and as "trivial beings." ${ }^{12} \mathrm{He}$ argues that since films are often seen as a slice of life, these negative representations shape the audience's conception of womanhood. To illustrate his point, he discusses the poor treatment of widows in Nollywood films, which are often set in the southeastern part of Nigeria, and how this has contributed to the belief that Igbo marriage will become a bitter-pill experience for a wife should she eventually lose her husband. Doki shares a personal experience of how Nollywood representations influence audiences. His brother refused to let Doki's niece marry a man from the eastern part of the country, telling his daughter to look at Nollywood films and see how widows are being mistreated in eastern Nigeria! Doki acknowledges that harmful widowhood practices do exist, but in the interests of positive national identity, he urges filmmakers to move beyond stereotypical portrayals of subjugated women, to reflect contemporary female achievements in politics, academia, and other spheres.

Aondowase Boh objects to the marginalized portrayal of women in Nollywood. He argues that their representation is institutionalized by patriarchal order, which insists that women should be limited to "traditional roles of housewives, cooks, and mothers." ${ }^{13}$ Boh agrees with his fellow critics that these are not realistic reflections, because in contemporary societies, women also occupy professional roles: "Women have distinguished themselves in their chosen endeavours as lawmakers, judges, lawyers, medical doctors, engineers, managing directors and Vicechancellors besides being housewives or mothers." ${ }^{14}$

Angell N. Yakubu also indicts Nollywood for its negative depictions of women, stating that the "image of womanhood should be positively promotional in films against the erstwhile portrayal of the negative image

\footnotetext{
12 Gowon A. Doki, "Reality versus Identity in Nollywood Movies: Reminiscences of a Womanist," Makurdi Journal of Arts and Culture 10, no. 1 (2012): 77.

13 Aondowase Boh, "Nollywood and National Development: Redefining Women's Role," Makurdi Journal of Arts and Culture 10, no. 1 (2012): 133.

14 Boh, "Nollywood and National Development," 133.
} 
The African Journal of Gender and Religion Vol. 26 No 1 (July 2020)

that characterize the industry." 15 In the same vein, Franca S. Jando comments, 'Women are being portrayed as 'plaything,' which undermines and limits women's dignity. Negative stereotypes of women are often portrayed, good-time-girls, free women, materialistic women who keep boyfriends, murdered, and wicked in-laws and as bitches often dressed in skimpy and pornographic outfits. In the church, women are presented as seducers of pastors and girls who are in the church to get boyfriends." 16

In short, analysts agree that Nollywood promotes unrealistic, unbalanced images of women. However, they do not consider how the filmmakers' own religion or production space might influence his or her representation and portrayal of women.

\section{The Feminization of Migration}

Over time, scholars have argued for the need to feminize migration theory, since classical migration theories excluded women as subjects. Marinucci explains that "the expression 'feminization of migration' started to be used, more frequently, to point out, generically, the changes that women went through in the last decades concerning the migratory context." ${ }^{17}$ Various research studies have revealed this gap in traditional migration theory, which neglected the importance of including women's experiences in the international migration process. Boyd and Grieco ${ }^{18}$ explain the inadequacies of research in the 1960s and 1970s, which theorized the experience of the male migrant and his family, thus making women only passive dependents and therefore an unimportant factor in the migratory phenomenon. The traditional approach to migration studies concealed women as a subject in the migration process, leading to their invisibility. Boyd and Grieco call for analyzing gender-specific experiences as a defining factor in the migration process, as one's gender can create very different migration experiences.

15 Angell N. Yakubu, "Nollywood and National Development a Feminist Perspective," Makurdi Journal of Arts and Culture 10, no. 1 (2012): 259.

16 France S. Jando, "Negative Images of Women in Nollywood Films: A Christian Perspective," Makurdi Journal of Arts and Culture 10, no. 1 (2012): 273.

17 Marinucci, "Feminization of migration?" 6.

18 Monica Boyd and Elizabeth Grieco, "Women and Migration: Incorporating Gender into International Migration Theory." Migration Information Source 1, no. 35 (2003): 7. 
Migration and the Feminization of Power: A Reading of Mike Bamiloye's Transnational Films

The invisibility of women in migration theory demands a feminist analysis. Boyd and Grieco echo feminist questions of how patriarchal systems affect and determine women's ability to migrate. How do women deal with gender relations, especially within the family, after migration? "In other words, how is patriarchy altered or reconstituted after migration?" 19 Feminist interrogation contributes to a female-centered theorizing of migration. Sadly, Oishi ${ }^{20}$ argues that as the number of women in the international migration process has increased, so has the abuse and exploitation of women. Many women migrants must earn their living in unskilled jobs rather than as professionals. Thus, the risk of abuse and exploitation increases.

Kevin Thomas and Ikubolajeh Logan ${ }^{21}$ examine the other side of the coin, taking a close look at African women's emigration to the United States and arguing that more than immigrants from any other continent, African women arrive in the United States as professionals with university degrees. Their role in the migration process is driven largely by a search for economic gain.

Afe Adogame summarizes film director Yemi Adepoju's thoughts on changing migration patterns, which breed change and sometimes a complete reversal in gender roles and identity. Adepoju explains that women's independent migration enables them to become active economically, as opposed to joining their husbands as dependents. Adepoju shows the increasing number of professional women emigrating from Africa to a more advanced economy, leaving husbands behind to act as primary caregivers to their children. ${ }^{22}$ Another pattern of women's emergence on the transnational scene is that women take on the role of breadwinner, with their migration leading eventually to the relocation of the whole family after them.

19 Boyd and Grieco. "Women and Migration," 3.

20 Nana Oishi, "Gender and Migration: An Integrative Approach" (2002).

21 Kevin J. A. Thomas and Ikubolajeh Logan, "African Female Immigration to the United States and Its Policy Implications," Canadian Journal of African Studies 46, no. 1 (2012): 87-107.

22 Afe Adogame, The African Christian Diaspora: New Currents and Emerging Trends in World Christianity. (London: Bloomsbury Academic, 2013): 12. 
The African Journal of Gender and Religion Vol. 26 No 1 (July 2020)

Marinucci categorizes the existing interpretations of the feminization of migration into three subgroups: quantitative feminization of migration (expressing an increase in female participation in the international migration process), visibility of female migrants (i.e., that they tend to remain invisible to migration analysis), and qualitative feminization of migration ("focused on the new profile of the contemporary migrant woman") ${ }^{23}$ Marinucci proposes a fourth category by calling for the possibility of a feminization of power. Power for women in this sense is defined as women's ability to make independent choices. ${ }^{24}$

The increasing awareness of and research into the role and peculiar experiences of women in migration practices is also evident in the onscreen world. With the advent of transnational films, filmmakers began to reflect more on the challenges of travelling to a new country as well as migrating. Nigerian transnational films are a good example of this shift. Nigerian transnational films are often made by Nigerian-based filmmakers. The films are usually given to exploring the cultural differences between the home country and the country that is visited.

The films reviewed below showcase this newly visible demographic of contemporary migrant women (i.e. their qualitative feminization) and also creates the possibility of a public discussion about the feminization of power. The female characters created by Bamiloye are financially independent women of economic means. However, to what extent and degree will Bamiloye allow for the feminization of their power? Will these new migrant women be permitted to make independent choices?

\section{Bamiloye's Production of Migrant Women}

Mount Zion Film Productions' films, more than those from most secular Nollywood filmmakers, deal with women's economic emancipation and the financial hardships that sometimes force men out of a job, thereby leading to the circumstantial emergence of women as co-breadwinners or even sole breadwinners. However, the transnational MZFP films also showcase,

23 Marinucci, "Feminization of Migration?" 13.

24 Marinucci, "Feminization of Migration?" 16. 
Migration and the Feminization of Power: A Reading of Mike Bamiloye's Transnational Films in detail, the conflict that emanates as a result of the emergence of female breadwinners.

On the national scene, Mount Zion video films also suggest a re-imagining of gender spaces as they construct images of economically emancipated women. In Foothold (2011), a woman named Funke builds a career with a highly reputable accounting firm and provides financial support for her family. In Broken Bridge (2012), the mother named Jadesola practically finances the household. She earns far more than her husband, so in the course of a crisis between the two, the husband moves out of the house. This is an acknowledgment of Jadesola's economic status as the primary breadwinner. In Enemy of My Soul (2003), Tejumade is the medical director at a pharmaceutical company, so, at the point of her divorce from Ore, she is not financially worse off. Even when Ore keeps begging Tejumade to return, she refuses to do so. She lives in a big, well-furnished apartment and works hard at her job to occupy her mind instead of worrying over her divorce.

All these women are portrayed as economically self-supporting, but they are also depicted as arrogant because of their economic status. At the end of the film, all three women return to and submit to their husbands' marital authority, though they retain their financial position. They are portrayed as having learned to value their husbands as the head of the family. Thus, these videos are one step ahead of popular Nollywood videos in their reflection of women's economic status, but they still show women reverting to traditional norms of marital authority. Analytically, we may argue that they reflect the film-maker's own response to economically independent women or more broadly, what they perceive as societal discomfort regarding the phenomenon of economically independent women. They are all economically advanced, yet through the films we are encouraged to see them as failures in their roles as wives and mothers. In this way, the three films reinforce the myth that independent, economic women are selfabsorbed and can hardly survive in marriage. Meanwhile, the husbands in these videos are portrayed to be more sinned against than sinning, more temperate and reasonable than their wives.

Not all transnational MZFP videos represent changing gender roles, as some of them still struggle with popular notions from the home country. In 
The African Journal of Gender and Religion Vol. 26 No 1 (July 2020)

A Crack in the Wall (2009), the stereotypical mother-in-law makes her way across the Atlantic, and harasses her daughter-in-law, Linda, after four childless years of marriage. Linda has undergone several fertility tests while her husband, Johnson - citing what seems to be a mix of African and Christian ideology - refuses to be tested, claiming that he was made perfect by God. But when his wife confronts him with the insinuation that he is probably unable to father a child, he augments his religious claims and slaps her, displaying a bruised male ego. Linda remains the stereotyped, sobbing Nollywood wife, who when childless is often besieged by both a mother-in-law and an unsupportive husband.

\section{The Return}

The first Bamiloye film that I will analyze in depth is The Return. In this film, Angelia is a Christian African immigrant in the United States. She is doing well financially, but she is single and greatly bothered by that fact. Angelia visits her pastor several times for prayers and encouragement. Eventually, she decides to visit her family back in Africa; within less than a month, she meets James, an usher in a Pentecostal church, and they get married. She returns to the United States to share her joy with her pastor, who does not receive the information as good news, faulting Angelia for her haste to marry a man she has barely met. Angelia secures a spousal visa for James, who migrates to the United States and gets a job. They have a daughter, who is six years old as the movie's plot unfolds. But the union is devoid of peace; Angelia and James are always fighting (the opening scene of the film shows one such fight).

In The Return, we see an extreme case of a woman playing the traditional cultural role normally expected of the husband, paying the wedding bills and taking responsibility for her husband's migration. As we watch the fights that ensue between them, we come to realize that Angelia is playing the traditional male role. In the heat of their argument, James says, "If I knew marrying you would be hell on earth, I would have never come to meet you here in the first place. ... There were ladies back home, dying to have my hand in marriage." This sounds very much like what ladies often tell their men as a form of boasting, but James reverses the roles. Angelia responds, "And if I had known bringing you here will make me miserable all my life, I would never have married you in the first place. James, there 
Migration and the Feminization of Power: A Reading of Mike Bamiloye's Transnational Films were eligible and more reasonable men contending to have my hand in marriage. But I opted for you, and I came to Africa to bring you."

James continues, "Because you paid for the things used for our wedding? Or because you paid for the ticket to bring me down here? Come on, go to church on Sunday and announce to the whole world that you filed for my paper to come here." All these comments establish the ways in which this relationship is not-normative in this case as women emerge as major economic actors in the migration process. This newly acquired status, however, continues to generate conflict in the private sphere of the James' and Angelia's home, especially given their cultural background.

When Angelia accuses her husband of being unreasonable with his continued late-night outings, James pounces on her; Angelia responds with a slap at James and immediately starts sobbing. This further infuriates James, who 'gives Angelia a beating'. We then see a flash-forward in which she imagines that she called the police to report this crime committed by James, causing him to become very fearful. But we later realize that she actually called her pastor instead of the police. Her pastor heaps blame on her, paying no attention to the physical abuse she has suffered from James. A two-man team (both a pastor and an elder) blame Angelia for not submitting to her husband and find it sacrilegious that she dares to slap her husband, even in self-defense. James is never reprimanded for his bad behavior. The pastor points out that even if she owns the house legally, James remains the head of the house.

From the following excerpt from the dialogue that ensues between Angelia, James, the elder, and the pastor, one can discern not just the conflict over role changes but also the transfer and infusion of African patriarchy of biblical hermeneutics from across the ocean:

Angelia: It has been like living in hell since we got married.

James: What are you waiting for? File for divorce. I am ready for it, you fool.

Angelia: No, you are the foolish one. 
The African Journal of Gender and Religion Vol. 26 No 1 (July 2020) James: Pastor, you can hear that! She called me a fool.

Pastor: Stop that, sister Angelia.

James: Say that again and I will give you three more hot slaps, in front of your pastor.

Angelia: And I vow with my life that you will never lay your hand on me again, James. I vow with my life! I will strip you naked and land you in jail. You will never see the light of the city. I will call the police on you I and will accuse you of murder, and I will do all I can to make you rot in jail all your miserable life! Idiot!

Pastor: Stop all this, sister Angelia!

James: Is that it?

Angelia: Yes, dare me. I have had enough of all this.

James: Pastor, please can you leave?

Angelia: No, Pastor, sit down! I bought this house. This house is mine. I have been paying the mortgage before I traveled to bring him from the hustling and bustling of Africa. This is my house, and I want you to stay.

Pastor: Sister Angelia, we must respect the wish of your husband; the Bible calls him your head. And we would advise that you respect and be submissive to him.

Angelia: Even when he is trying to kill me, Pastor?

The husband walks away, and so do the pastor and elder. Angelia is left alone. From this excerpt, it is evident that the pastor and James remain committed to their traditional gender constructs of the male breadwinner. In contrast, Angelia lives in the current reality of her status as the breadwinner, asking the pastor to remain because she owns the house (playing the role of the financier, who typically calls the shots). Angelia's role is entirely a reversal of what has traditionally been perceived as the 
norm. She plays the traditional role of the man, who typically goes in search of greener pastures and then comes back for a wife to join him in the newly discovered world. In this instance, Angelia goes to the United States and then returns to Africa in search of a husband. However, conflict arises when James will not accord her the respect and appreciation traditionally accorded to the breadwinner.

Boyd and Grieco suggest that if a female migrant acquires a new economic status, her authority within the household might expand. ${ }^{25}$ In contrast to this expectation, Angelia's condition does not automatically change. She has to keep fighting for the acknowledgment of her economic standing, which in her mind should place her in a position of authority as breadwinner or at least co-breadwinner. Though Angelia is aware of her rights in the host country, she is also curbed by traditional thinking, represented by the transnational church and its leaders. In the heat of the moment, Angelia had vowed to invoke the full weight of the law on James. But her pastor says that her only options are patience and prayer. The pastors represent a traditional mindset, which is perpetuated both in her home country and by the church in her new country. Angelia attends a Nigerian transnational church, and one consistent feature of these churches is that they are led by migrants. Thus, the transnational churches maintain close relationships with Africa, and their doctrine is also influenced by Christianity as practiced back home, which is woven together with the indigenous culture. (MZFP itself is an example of such transmigrant activities, as Bamiloye and his Nigerian crew travel back and forth regularly.)

\section{The Prodigal Ones}

The Prodigal Ones tells the story of a Nigerian couple who have migrated to the United States. As the film opens, Rosy and Ade seem financially established; they can attend an influential party, live in a well-furnished house, drive flashy cars, shop endlessly, and still keep up with the mortgage and other bills. However, as they progress socially and economically, they regress spiritually, and their church participation dwindles. Their pastor tries to warn them, but they don't listen, and so 'calamity' starts to unfold. Soon the entire family is engulfed in one problem

Boyd and Grieco. "Women and Migration," 7. 
The African Journal of Gender and Religion Vol. 26 No 1 (July 2020)

after another. Like the prodigal son in the Bible, Rosy and Ade realize their negligence toward God and church activities. Rosy calls on the pastor for prayer, and he leads the family back to Christ. Then the storm ceases and the family's peace is restored.

In The Prodigal Ones, Rosy and her friends Jenifer and Lola are profiled as economically independent women. Rosy contributes a higher percentage of the house mortgage. Jenifer subverts the traditional gender role of the husband who goes out in search of greener pastures: she is working in the United States and sending money to her husband. Lola celebrates her status as a single mother: "It is nice being a single mother. You know, it makes you as free as a bird in the sky." When other ladies tell Lola what she is missing, she responds

"Yes, I love what I'm missing. I miss a man bossing over me putting his feet in a pouffe waiting for his meal while I sweat out in the kitchen. I miss a man tailoring my movements [and] shielding me away from fun and good parties. I miss the God-forsaken fool that paraded himself as my husband for three good years. Well, after being in and out of marriage three times now, I conclude it is best being a single mother."

Lola is portrayed as being greatly influenced by Western liberalism and moral bankruptcy. Back home in Africa, she would not announce so boldly that she has been in and out of marriage three times.

When Jenifer mentions that she needs to send money to her husband, Lola, portrayed as the liberal, lashes out at her: "I hate the idea of someone controlling my spending from Africa while I breast the heat and shoulder the winter here ... you work for your money, spend it on yourself." Lola convinces Jennifer to divert the money meant for her husband to some lace clothing material for a party. Jenifer represents the new profile of African migrant women who are emerging as key actors in international migration.

Rosy emerges from the kitchen to answer her husband's query about her purchase of a piece of lace fabric that she bought while out with her friends. She eventually reminds him that she was spending her own earnings: "Is it not my money? I worked for my money, leave me alone." 
Migration and the Feminization of Power: A Reading of Mike Bamiloye's Transnational Films

Rosy echoes Lola's ideas about women managing their own finances and not being managed by their husband. Ade, in the traditional patriarchal tone, questions Rosy's spending; he believes that Rosy is mismanaging her funds. But Rosy quickly also points out that Ade too wastes his resources on countless wristwatches, perfumes, and useless electronic gadgets. "Ade," she says, "If I blow up my money, it is because I work for it."

In various ways, Rosy tries to bring to Ade's consciousness her new identity as co-breadwinner. She seeks every avenue to invoke her authority as a co-head of the family. One of their conversations demonstrates this:

Rosy: You talk to this boy as if you solely own this house.

Ade: Yes, I am your husband, I own this house.

Rosy: You are speaking Bible; I speak legality here, husband. We own this house together. I pay sixty percent of the mortgage, remember, so stop threatening my son.

Ade: What has gotten into your head, Rosy?

Rosy: You want to know what has gotten into my head? Illumination, and a sudden realization of the fact that a man who does not own up to fifty percent of the shares in this house is trying to call the shots.

This dialogue shows both the wife's economic empowerment and the conflict that results from this economic arrangement. Rosy's economic advancement does not grant her an automatic new identity at home. The continuous conflict between Rosy and Ade is a tussle for domestic authority. The conflict is complicated because Ade's religious standing is at odds with Rosy's legal claims.

\section{The Finest Wine}

Marcia and Raymond are African immigrants living in Washington, D.C., with two sons preparing to go to university. The family is going through economic hardship, as the couple is out of work and the bills keep piling up. Marcia gets a temporary offer as a chaplain at a correctional center in 
The African Journal of Gender and Religion Vol. 26 No 1 (July 2020)

Canada. After much deliberation, the family decides to relocate. Marcia's job as a chaplain is to demonstrate that spiritual intervention can help to solve societal ills.

While Marcia and Raymond manage their economic condition in a way that makes Marcia the breadwinner and Raymond dependent on her, other couples in the film are unable to do the same. Two men, Ruben and Roggers, compare notes on their state and the economic crisis that that is endangering their "lordship" and breadwinner status. Ruben tells Roggers, "I cannot believe that I could be thrown out of my house like that. ... I mean, I cannot believe that a woman I labored and slaved to bring to this land will be the one to call the police on me." Roggers responds, "Well, Ruby, as I told you, I kicked the terrible woman in my house in the tummy so hard that she knows who the boss is. Just because I lost my job shouldn't give her the liberty to turn me into her houseboy." The conversation continues:

Ruben: She treats you like a houseboy? Did you kick her in the tummy?

Roggers: Ruby, I had to do what I did to prove to her who I really am. I am a man and her husband, for that matter.

Ruben: Roggers, I don't think it was a smart move. You don't want to make the same mistake I made, do you?

Roggers: What mistake?

Through a flashback, we see Ruben's error. He got into a fight with Rachel, his wife, and beat her up. Rachel called the police on him. She cried out as she made her way to the phone, "I will tell you, this is Canada, and this is not Africa." Ruben was removed from the house and now lives in a public shelter. Despite Ruben's compelling story, Roggers refuses to yield: "No, no, I now have my mind made up. I am going to assert my leadership as the boss. No one dare question me in Africa, so why should I give an inch here?" Ruben replies softly, "Well, Roggers, that was Africa; this is Canada." 
Migration and the Feminization of Power: A Reading of Mike Bamiloye's Transnational Films

Bamiloye is not critical of or disturbed by the new profile of African migrant women. This is evident in all three case study films, as he profiles his female characters as economically independent. Nevertheless, he is concerned with the implications of their rising position in the private sphere, seeking to retain the husband as head of the family regardless of his economic status. Bamiloye resolves the conflicts following a biblical hermeneutic that establishes the husband as the head of the wife, along with the submissive position that wives must maintain. The films avoid the associated biblical injunction that demands men must love their wives, giving the responsibility for preserving sanity at home solely to the wives. Bamiloye avoids passing judgment on practical issues like household chores. If a wife becomes the main breadwinner, either temporarily or permanently, should the man also settle into the role of housekeeping? Roggers in The Finest Wine sees this switch as degrading and becomes physically abusive to his wife. Bamiloye is silent on such matters, but he emphasizes the wife's responsibility to be submissive.

\section{Conclusion}

Literature on the representation of women in Nollywood shows the misrepresentation of women in Nollywood films. This article, through analysing three films representative of the evangelical brand of Nollywood films produced on the transnational scene, examines how factors of culture and religion can influence and alter a gender perspective. The analysis of the selected films examines the portrayal of the economic improvement and the representation of the lives of emancipated women. The images of women in these films showcase the challenges women face in negotiating a new profile that departs from traditional economic arrangements in the family. Most women in Bamiloye's case study films are empowered and assertive women. However, they struggle to gain acknowledgment of that power from their spouses and other men in their community, including religious representatives.

The transnational MZFP films portray the changes in gender roles that have resulted from the emergence of the new, economically progressive woman encouraged by migration opportunities. Their roles remain contested within the domestic sphere of the home where the economic advancement of a wife does not grant her an automatic new identity as someone who is also free of her husband's marital authority. The 
continuous conflict between husbands and wives, such as the example of Roggers and his wife, is a tussle for domestic authority. If a wife evolves to become the breadwinner paying the bills, should not the husband also become amendable to take up domestic work?

Bamiloye reflects on the realities of the new profile women, but his treatment of the challenges they face suggest that he is blind to the adjustments in family living that must accompany these changes. The films thus left a lot of questions unanswered. What gender identity should these women adopt? Should they pretend to be ignorant of the implications of their new economic status and take a back seat at home? Should they remain submissive, knowing that their submission can sometimes be defined as submitting one's finances to the sole management of a husband?

Many questions remain unanswered here. How should women appropriate the changed gender identities that arise from their self-development process? Is women's economic power a possibility within the private sphere of the family? Rosy in The Prodigal Ones told her husband, "You are speaking Bible; I speak legality here." So should Christian women "speak legality" or "speak Bible"?

The qualitative feminization of migration is evident in these videos, but the feminization of economic power in the family for which Marinucci calls is absent. Women are not trusted to perform their new social and economic identities. Instead, many male voices tell women how to practice their new roles, while remaining subservient to male marital authority. As more women emerge as economically powerful, it is essential for media portrayals to suggest ways of appropriating the new profile of women in both national and transnational spaces by sharing the lived experiences of contemporary women. This message is especially important for women raised on continents where economically empowered women still are seen as a threat to the traditional order. 
Migration and the Feminization of Power: A Reading of Mike Bamiloye's Transnational Films

\section{References}

Adejunmobi, Moradewun. "Charting Nollywood's Appeal Locally and Globally." African Literature Today 28 (2010): 106-21.

Adejunmobi, Moradewun. "Nollywood, Globalization, and Regional Media Corporations in Africa." Popular Communication 9, no. 2 (2011): 67-78.

Adeleye-Fayemi, Bisi. "Either One or the Other: Images of Women in Nigerian Television." In Readings in African Popular Culture, edited by Karin Barber, 125-131. Bloomington: Indiana University Press, 1997.

Adogame, Afe. The African Christian Diaspora: New Currents and Emerging Trends in World Christianity. London: Bloomsbury Academic, 2013.

Boh, Aondowase. "Nollywood and National Development: Redefining Women's Role." Makurdi Journal of Arts and Culture 10, no. 1 (2012): 128-41.

Boyd, Monica, and Elizabeth Grieco. "Women and Migration: Incorporating Gender into International Migration Theory." Migration Information Source 1, no. 35 (2003): 1-7.

Ellapen, Jordache, and Jyoti Mistry. "Nollywood Transportability: The Politics and Economics of the Video Films as Cultural Products." In Global Nollywood: The Transnational Dimensions of an African Video Film Industry, edited by Matthias Krings and Onookome Okome, 46-69. Bloomington: Indiana University Press, 2013.

Gowon, Doki A. "Reality versus Identity in Nollywood Movies: Reminiscences of a Womanist." Makurdi Journal of Arts and Culture 10, no. 1 (2012): 74-84.

Haynes, Jonathan. "The Nollywood Diaspora: A Nigerian Video Genre." In Global Nollywood: The Transnational Dimensions of an African 
The African Journal of Gender and Religion Vol. 26 No 1 (July 2020)

Video Film Industry, edited by Matthias Krings and Onookome Okome, 73-99. Bloomington: Indiana University Press, 2013.

Hoffmann, Claudia. "Made in America: Urban Immigrant Spaces in Transnational Nollywood Films." In Global Nollywood: The Transnational Dimensions of an African Video Film Industry, edited by Matthias Krings and Onookome Okome, 121-138. Bloomington: Indiana University Press, 2013.

Jando, S. France. "Negative Images of Women in Nollywood Films: A Christian Perspective." Makurdi Journal of Arts and Culture 10, no. 1 (2012): 272-82.

Jedlowski, Alessandro. "From Nollywood to Nollyworld: Processes of Transnationalization in the Nigerian Video Film Industry." In Global Nollywood: The Transnational Dimensions of an African Video Film Industry, edited by Matthias Krings and Onookome Okome, 25-45. Bloomington: Indiana University Press, 2013.

Marinucci, Roberto. "Feminization of migration?" Revista Interdisciplinar da Mobilidade Humana 15, no. 29 (2007): 5-22.

Odi, Christine. "Nollywood Mothering: Motherhood in Selected Nigerian Films." Makurdi Journal of Arts and Culture 10, no. 1 (2012): 58-73.

Oishi, Nana. "Gender and Migration: An Integrative Approach." CCIS Working Paper No. 49, Center for Comparative Immigration Studies, University of California, San Diego (2002). https://escholarship.org/uc/item/os04g29f

Okome, Onookome. "Women, Religion and Video Film in Nigeria." Film International, 2, no 1 (2004): 4-13.

Pype, Katrina. "Religion, Migration, and Media Aesthetics: Notes on the Circulation and Reception of Nigerian Films in Kinshasa," In Global Nollywood: The Transnational Dimensions of an African Video Film Industry, edited by Matthias Krings and Onookome Okome, 199-222. Bloomington: Indiana University Press, 2013. 
Migration and the Feminization of Power: A Reading of Mike Bamiloye's Transnational Films Thomas, J. A. Kevin, and Ikubolajeh Logan. "African Female Immigration to the United States and Its Policy Implications." Canadian Journal of African Studies 46, no. 1 (2012): 87-107. https://doi: 10.1080/00083968.2012.659582

Usman, Kabir Asabe, and Umar Aisha Muhammad. "Women in Hausa Home Movies: Lessons from Kirji Biki (Master of Ceremony)." Makurdi Journal of Arts and Culture 10, no. 1 (2012): 25-36.

Yakubu, N. Angell. "Nollywood and National Development: A Feminist Perspective." Makurdi Journal of Arts and Culture 10, no. 1 (2012): 246-61. 


\section{Videography}

A Crack in the Wall. Written by Wole Adeyi. Directed by Mike Bamiloye. Ile-Ife, Nigeria: Mount Zion Film Productions, 2009.

Broken Bridge. Written and directed by Mike Bamiloye. Ile-Ife, Nigeria: Mount Zion Film Productions, 2012.

Dangerous Influence. Written and directed by Mike Bamiloye. Ile-Ife, Nigeria: Mount Zion Film Productions, 2012.

Enemy of My Soul. Written and directed by Mike Bamiloye. Ile-Ife, Nigeria: Mount Zion Film Production, 2003.

Foot Hold. Written and directed by Elvon Jarrett and Yemi Adepoju. IleIfe, Nigeria: Mount Zion Film Productions, 2011.

The Finest Wine. Written and directed by Mike Bamiloye. Ile-Ife, Nigeria: Mount Zion Film Productions, 2013.

The Prodigal Ones. Written and directed by Mike Bamiloye. Additional script by Margaret Anenih. Ile-Ife, Nigeria: Mount Zion Film Productions, 2008.

The Return. Written and directed by Mike Bamiloye. Ile-Ife, Nigeria: Mount Zion Film Productions, 2014. 